JOURNAL OF TOURISM, HOSPITALITY AND ENVIRONMENT MANAGEMENT (JTHEM)

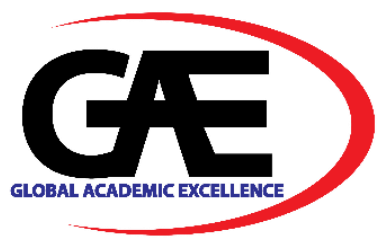

\title{
KNOWLEDGE, ATTITUDES AND PRACTICES OF COMMUNITIES TOWARDS SOLID WASTE MANAGEMENT IN VINH TRUNG COMMUNE, HAU GIANG PROVINCE, VIETNAM
}

\author{
Nguyen Thanh Giao ${ }^{1 *}$ \\ 1 College of Environment and Natural Resources, Can Tho University, Vietnam \\ Email: ntgiao@ctu.edu.vn \\ * Corresponding Author
}

\section{Article Info:}

Article history:

Received date: 18.02 .2021

Revised date: 01.03 .2021

Accepted date: 04.04.2021

Published date: 10.06 .2021

\section{To cite this document:}

Giao, N. T. (2021). Knowledge, Attitudes And Practices Of Communities Towards Solid Waste Management In Vinh Trung Commune, Hau Giang Province, Vietnam. Journal of Tourism, Hospitality and Environment Management, 6 (23), 01-09.

DOI: $10.35631 / J T H E M .623001$.

This work is licensed under $\mathrm{CC}$ BY 4.0

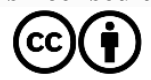

\begin{abstract}
:
The study was conducted to preliminary evaluate knowledge, attitudes, and practices (KAP) of communities regarding solid waste management in Vinh Trung commune, Vi Thuy district, Hau Giang province using a questionnaire survey. The results of this study show that the amount of solid waste was generated ranged from $0.5-1.2 \mathrm{~kg}$ per household per day with an average of $0.24 \mathrm{~kg}$ per capita per day. The household solid waste contained organic waste $(85.43 \%)$, reusable waste $(13.94 \%)$, and other components $(0.64 \%)$. Most people (>90\%) have knowledge about the effects of solid waste disposal on environmental quality, and the benefits of source separation via television and radio. Local authorities have not done well in improving communities' awareness. The participants have very good attitudes in being willing to sort, pay the garbage collection fee, help each other to increase public awareness. However, the investigated results of the practice survey were contrary to the results with knowledge and attitudes. Therefore, it is very important to provide the public with solid waste management infrastructure and simultaneously support the local authorities in raising propaganda about waste separation and recycling activities.
\end{abstract}

Keywords:

Solid Waste, Knowledge, Attitudes, Practices, Hau Giang Province, Pollution, Waste Separation

\section{Introduction}

Solid waste management is currently a problem for many developing countries in the world [13]. Vietnam is one of the most densely populated countries in Southeast Asia about 97,338,579 people in 2020. Due to the industrialization and modernization process, this country has achieved remarkable socio-economic development. However, population growth and fast Copyright $\odot$ GLOBAL ACADEMIC EXCELLENCE (M) SDN BHD - All rights reserved 


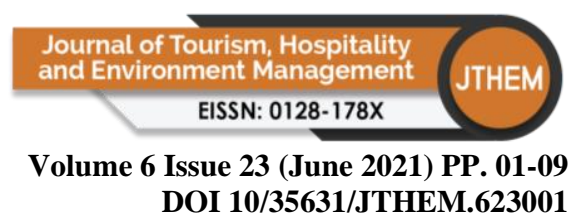

economic development have resulted in many negative environmental impacts which become a challenge for sustainable development in many countries. In 2019, the amount of solid waste in urban areas was generated about 35,624 tons/day with a collection rate of about $92 \%$; meanwhile, the generation rate in rural areas was up to 28,394 tons/day, but the collection was still very low, only about $66 \%$ [4]. With the average rate of solid waste generation of 0.82 $\mathrm{kg} / \mathrm{capita} /$ day (urban areas) and $0.45 \mathrm{~kg} / \mathrm{capita} /$ day (rural areas), the Mekong Delta region has a high volume of solid waste, which was about 9,429 tons/day. The rates of collection in rural and urban areas are $49.1 \%$ and $88.3 \%$, respectively. In which, Hau Giang province is located in the center of the Mekong Delta, currently has 7 administrative units including five districts (Phung Hiep, Long My, Vi Thuy, Chau Thanh and Chau Thanh A) and two towns (Nga Bay and Vi Thanh). The volume of domestic solid waste increased significantly in the period 2010 (105 tons/day) - 2019 (782 tons/day), with the generation index of about $1.07 \mathrm{~kg} / \mathrm{capita} / \mathrm{day}$ [4]. Vi Thuy district is an open-door district has important contribution in the provincial economic development. Specifically, economic conditions have developed in many fields, including agriculture in recent years, including agriculture, industry and services. Therefore, the demand for quality of life is increasing day by day, which makes the volume of domestic waste increasing strongly, which is organic and not from organic origin. These wastes did not decompose or take a lot of time to decompose. Therefore, improper solid waste management can have negative effects on the environment and human health [1-3, 5]. However, in fact, effectively solving the problem of solid waste requires investment in manpower, science and technology. Meanwhile, community participation in solid waste management is one of the appropriate problem-solving measures, which has been applied by many researchers in the past [6-9]. This may be a more practical method than research focusing solely on technology. The study was conducted to preliminary assess knowledge, attitudes and practices of communities towards solid waste management in Vinh Trung commune, Vi Thuy district, Hau Giang province.

\section{Materials and Methods}

The field solid waste investigation, survey and sampling methods are implemented to calculate the amount of solid waste generated in the study area. Solid waste samples were collected by distributing plastic bags to the local people (15 household) living in Vinh Trung commune, Vi Thuy district, Hau Giang province to store household wastes for a period of 7 consecutive days (from Monday to Sunday). These bags were then collected every day at 17:00 to separate collected household waste at the lab area according to the guidance of the Ministry of Natural Resources and Environment. Generally, the datasets constructed in this study include 15 samples/day $\times 7$ days. Amount of waste was weighted and recorded for each household. Besides that, the average amount of solid waste produced based on the rate of generation and total population of the study area can be calculated using Equation (1):

$$
\mathrm{Y}=\mathrm{A} \times \mathrm{B} \quad(1)
$$

where, $\mathrm{Y}$ is total amount of generated solid waste $(\mathrm{kg} / \mathrm{day}) ; \mathrm{A}$ is the amount of waste generated per capita per day (kg/capita/day); B is the total population of the study area (people).

The questionnaire survey was carried out face-to-face to evaluate knowledge, attitudes and practices (KAP) of communities concerning the solid waste management. Nine questions were asked for the knowledge including means used to update information about solid waste management, reducing method for domestic wastes, the benefits of waste segregation, environmental impacts of waste disposal, knowledge of plastic bags biodegradation, human health and ecological effects of improper waste disposal, and price of recycling wastes (Table 


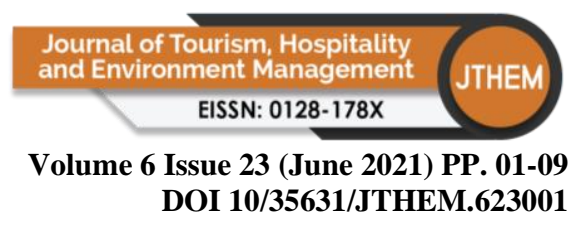

1). People's knowledge was assessed based on the number of points given for each question. There were 9 questions in which 5 questions (from 2 to 6) were evaluated based on their answers in the first question (17 points maximum for 5 questions). The remaining questions were used to evaluate the level of knowledge of the respondents in practical.

Table 1. Questionnaire Survey to Evaluate the Respondent's Knowledge

\begin{tabular}{|c|l|}
\hline $\begin{array}{c}\text { Question } \\
\text { no. }\end{array}$ & \multicolumn{1}{|c|}{ Items } \\
\hline 1 & $\begin{array}{l}\text { What means have you used to update information about solid waste } \\
\text { management? }\end{array}$ \\
\hline 2 & How can we reduce domestic waste? \\
\hline 3 & What are the benefits of waste segregation? \\
\hline 4 & What are the environmental impacts of waste disposal? \\
\hline 5 & Are plastic bags biodegradable? \\
\hline 6 & What are the human health effects of waste disposal? \\
\hline 7 & Where is the appropriate garbage separation? \\
\hline 8 & What extent do waste collection sites affect travel, aesthetics and human health? \\
\hline 9 & What is the price of recycling waste? \\
\hline
\end{tabular}

People's attitudes towards solid waste management were assessed by collecting relevant information including collection time, satisfaction with the current waste collection, willingness to pay the waste collection fee, willingness to separate wastes and share experiences to everyone around, agreement with placing landfill in the community, appropriate waste collection methods, and ways of accessing proper knowledge of solid waste management (Table 2).

Table 2. Questionnaire Survey to Evaluate the Respondent's Attitudes

\begin{tabular}{|c|c|}
\hline $\begin{array}{l}\text { Question } \\
\text { no. }\end{array}$ & Items \\
\hline 1 & Is waste collection time reasonable? \\
\hline 2 & Are you satisfied with your current waste collection? \\
\hline 3 & $\begin{array}{l}\text { Would you be willing to separate your waste if it provided a better living } \\
\text { environment? }\end{array}$ \\
\hline 4 & Are you willing to pay the waste collection fee? \\
\hline 5 & $\begin{array}{l}\text { If you know how to separate waste, are you willing to share with everyone } \\
\text { around? }\end{array}$ \\
\hline 6 & Do you agree to place a landfill in the commune? \\
\hline 7 & What are the appropriate waste collection methods? \\
\hline 8 & $\begin{array}{l}\text { What are the appropriate methods to learn and access knowledge about solid } \\
\text { waste management? }\end{array}$ \\
\hline
\end{tabular}

Regarding the practices toward solid waste management, the questions of participating in remediating environmental pollution, household garbage containers, agreement in sorting wastes, ways of household wastes disposal, attitudes toward improper wastes disposal, and recommendations for solid waste management (Table 3). This information is collected directly from local people; therefore, the results of the topic depend on local practices is very large. The calculation of the amount of generated solid waste was presented in 3 types, including 


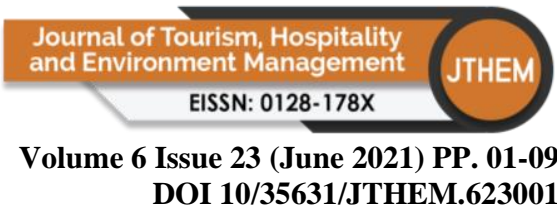

$\mathrm{kg} /$ household/week, kg/household/day, kg/capita/day. In this study, Microsoft Word and Excel (Microsoft Crop., Washington, USA) softwares were used to synthesize and analyze the research results.

Table 3. Questionnaire Survey to Evaluate the Respondent's Practices

\begin{tabular}{|c|l|}
\hline $\begin{array}{c}\text { Question } \\
\text { no. }\end{array}$ & \multicolumn{1}{|c|}{ Items } \\
\hline 1 & $\begin{array}{l}\text { Evaluate the level of remediating the environmental pollution caused by } \\
\text { themselves? }\end{array}$ \\
\hline 2 & $\begin{array}{l}\text { What have you done to alleviate the environmental pollution caused by } \\
\text { domestic waste? }\end{array}$ \\
\hline 3 & What is your household garbage container? \\
\hline 4 & Have you sorted your domestic waste? \\
\hline 5 & How do you dispose of your domestic waste? \\
\hline 6 & How do you dispose of your broken electronic devices? \\
\hline 7 & What would you do if you saw someone litter indiscriminately? \\
\hline 8 & $\begin{array}{l}\text { What are your recommendations for solid waste management in your } \\
\text { commune? }\end{array}$ \\
\hline
\end{tabular}

\section{Results and Discussion}

\section{Respondent Characteristics}

All participants are Kinh ethnic group including $67 \%$ of males and $33 \%$ of females. They were in the age-group of 37-67 years. The educational level can be divided into the illiterate level, elementary, secondary school and high school account for 33\%, 40\%, $20 \%$ and $7 \%$, respectively. Most of the responders $(66.67 \%)$ are farmers with income per capita of 2,900,000 $\mathrm{VND} / \mathrm{month}$. This income is still low compared to the urban area.

\section{Solid Waste Generation}

The results of this study showed that the amount of domestic waste production was ranged from 0.5 to $2 \mathrm{~kg} /$ day depending on the number of members and the average income of each household. The generated solid waste was ranged from $0.5-1 \mathrm{~kg} / \mathrm{day}, 1-2 \mathrm{~kg} / \mathrm{day}$, and lower 0.5 $\mathrm{kg} /$ day accounted for $56.67 \%, 26.67 \%$, and $16.67 \%$, respectively (Table 4 ).

The highest and lowest amount of produced domestic waste were $0.39 \mathrm{~kg} / \mathrm{capita} /$ day and 0.18 $\mathrm{kg} / \mathrm{capita} /$ day, respectively. The average amount of this production per capita $(0.24 \mathrm{~kg} / \mathrm{day})$ in the study area is lower than that amount in rural areas (0.45 kg/capita/day) [4, 10-11]. The highest proportion of household waste was organic waste at $88.9 \%$ and followed by the reusable waste at $11.1 \%$. The remaining types of waste that do not include hazardous waste accounted for a negligible proportion.

Table 4. Domestic Waste Production in Vinh Trung, Vi Thuy, Hau Giang Province

\begin{tabular}{|c|c|c|c|c|}
\hline \multirow{2}{*}{ Household } & \multirow{2}{*}{ Members } & \multicolumn{3}{|c|}{ Amount of domestic waste production } \\
\cline { 3 - 5 } & & $\mathbf{k g} /$ household/week & $\mathbf{k g / h o u s e h o l d / d a y ~}$ & $\mathbf{k g / c a p i t a / d a y ~}$ \\
\hline 1 & 5 & 7.80 & 1.11 & 0.22 \\
\hline 2 & 4 & 6.90 & 0.99 & 0.25 \\
\hline 3 & 3 & 8.20 & 1.17 & 0.39 \\
\hline
\end{tabular}




\begin{tabular}{|c|c|c|c|c|}
\hline 4 & 2 & 3.80 & 0.54 & 0.27 \\
\hline 5 & 4 & 6.70 & 0.96 & 0.24 \\
\hline 6 & 4 & 6.40 & 0.91 & 0.23 \\
\hline 7 & 4 & 7.00 & 1.00 & 0.25 \\
\hline 8 & 3 & 3.60 & 0.51 & 0.17 \\
\hline 9 & 5 & 7.40 & 1.06 & 0.21 \\
\hline 10 & 2 & 3.90 & 0.56 & 0.28 \\
\hline 11 & 5 & 7.30 & 1.04 & 0.21 \\
\hline 12 & 4 & 6.70 & 0.96 & 0.24 \\
\hline 13 & 5 & 6.30 & 0.90 & 0.18 \\
\hline 14 & 5 & 8.20 & 1.17 & 0.23 \\
\hline 15 & 3 & 3.80 & 0.54 & 0.18 \\
\hline Average & & $\mathbf{6 . 2 7}$ & $\mathbf{0 . 9 0}$ & $\mathbf{0 . 2 4}$ \\
\hline
\end{tabular}

The average amount of generated solid waste was $0.9 \mathrm{~kg}$ per household per day, and each person can produce $0.24 \mathrm{~kg}$ /day. With a population of 13,688 people in 2019 , the commune can produce up to 3.23 tons of waste per day. However, the waste collection in rural areas (especially in remote areas) does not occur at all or not enough [4]. It is predicted that in the next 5 years, the amount of domestic waste will reach about 23 tons/day when the population of the commune increases to 95,816 people. Meanwhile, there is currently no waste collection system, all generated waste is discharged directly into the environment or treated in-situ with improper methods. With this situation, the problem of solid waste will put pressure on the collection, treatment and environmental landscape in the area.

\section{Knowledge, Attitudes and Practices of Communities Towards Solid Waste Management}

Knowledge: Table 1 presents the questions were used to aske during the interview to assess knowledge of the communities about solid waste management. The majority of respondents agreed that they could access information about solid waste management via television and radio. In addition, a few of them got updates from the internet and newspapers. None of the surveyed households received information from the local authorities where they live. From the above results, it can be seen that the respondent's access to information is only at an average level and has not actively participated in information dissemination from local authorities. The score showing people's knowledge level was relatively high (17 points, correctly answered all questions), accounted for $63.33 \%$, the lowest score was 12 points, accounted for $6.67 \%$. Therefore, it can be concluded that people have basic knowledge about solid waste management even though their ability to access information is only average.

All participants believed that the appropriate waste separation should be at their home. There were $83.3 \%$ of responders agreed that the garbage collection location have a very high impact on the aesthetic area and human health, while $16.7 \%$ thought that there is no effect. For question 9, most of the responders said that the price for recyclable waste ranges from 2000 to 6000 $\mathrm{VND} / \mathrm{kg}$ depending on the type and price fluctuations in the market.

Attitudes: To assess the respondents' attitudes towards solid waste management in rural areas, eight questions were provided (Table 2). In particular, the first two questions related to garbage collection were skipped because there is currently no local waste collection system. The next four questions were in form of closed-ended questions, and the other two were opened-ended questions. 


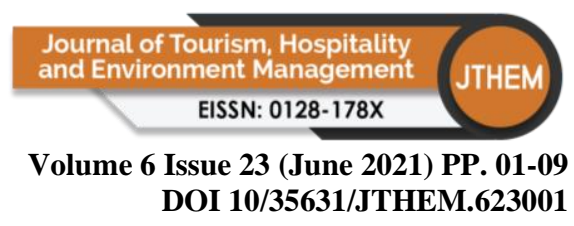

Most of the interviewees (86.7\%) are willing to classify waste if it brings the good environment. On the contrary, some of them $(13.3 \%)$ are not willing to do this because they do not have time or knowledge about waste separation. They believe that this would be done better by garbage collectors. All participants are willing to pay for garbage sorting fee and share their information about how to separate solid waste. The fee that they are willing to pay for garbage collection is 3,000 VND per household per month, which is the same as the current rates in some rural areas. Furthermore, about $33.33 \%$ out of total would agree to pay the garbage collection fee of $5,000 \mathrm{VND}$ per household per month if the garbage collectors were to take care of the sorting. The difference between this willingness to pay levels depends on the income of each household. In addition, according to reported by Nam (2016) [12], occupations of different household heads are negatively affecting their willingness to pay service costs. However, when asked about landfill planning, $100 \%$ of the answers do not agree with the landfill located in the area where they live. They believed that the operation of landfill can affect the regional aesthetics, cause odors, appear many flies and affect their health. The method of waste collection that everyone agrees is to use public waste storage bins that will be placed in a convenient location.

Practices: All participants answered eight questions to evaluate their practices in the solid waste management and then determined the relationship between knowledge, attitudes, and practices (Table 3). The percentage of respondents who assessed the level of remediation of environmental pollution caused by them is high (33.33\%), medium (42.42\%), and low $(24.25 \%)$. However, none of those interviewed believe that they have alleviated environmental pollution at a very high level.

The responses of the participants in question 2 show that they have not yet taken any specific actions to reduce the environmental pollution. For example, the respondents did not separate waste at source and preferred to use plastic bags. This can be explained by the convenience of these plastic bags, the lack of knowledge about how to separate waste, as well as the lack of local waste collection systems. In addition, the garbage containers are still rudimentary, not hygienic, and are often reused from used buckets and plastic bags. There are three main methods to dispose their daily waste including thrown away into the environment $(63.33 \%)$, open-burned (26.67\%), and buried in the ground (10\%). This situation has also happened in some other rural areas, because the proportion of waste collected is quite low, so people often bury near their home, burn or discharge directly into the river [13]. These treatments can seriously affect the environmental quality and human health. For example, the disposal of garbage into river systems can reduce water quality that is used for human consumption as well as the development of aquatic and plant species. This information has been reported in many previous studies, which suggested that solid waste, leachate affected the soil environment, water quality, phytoplankton and zoobenthos [13-15]. Moreover, it may affect crop growth due to the difficulty of decomposition of plastic products. 


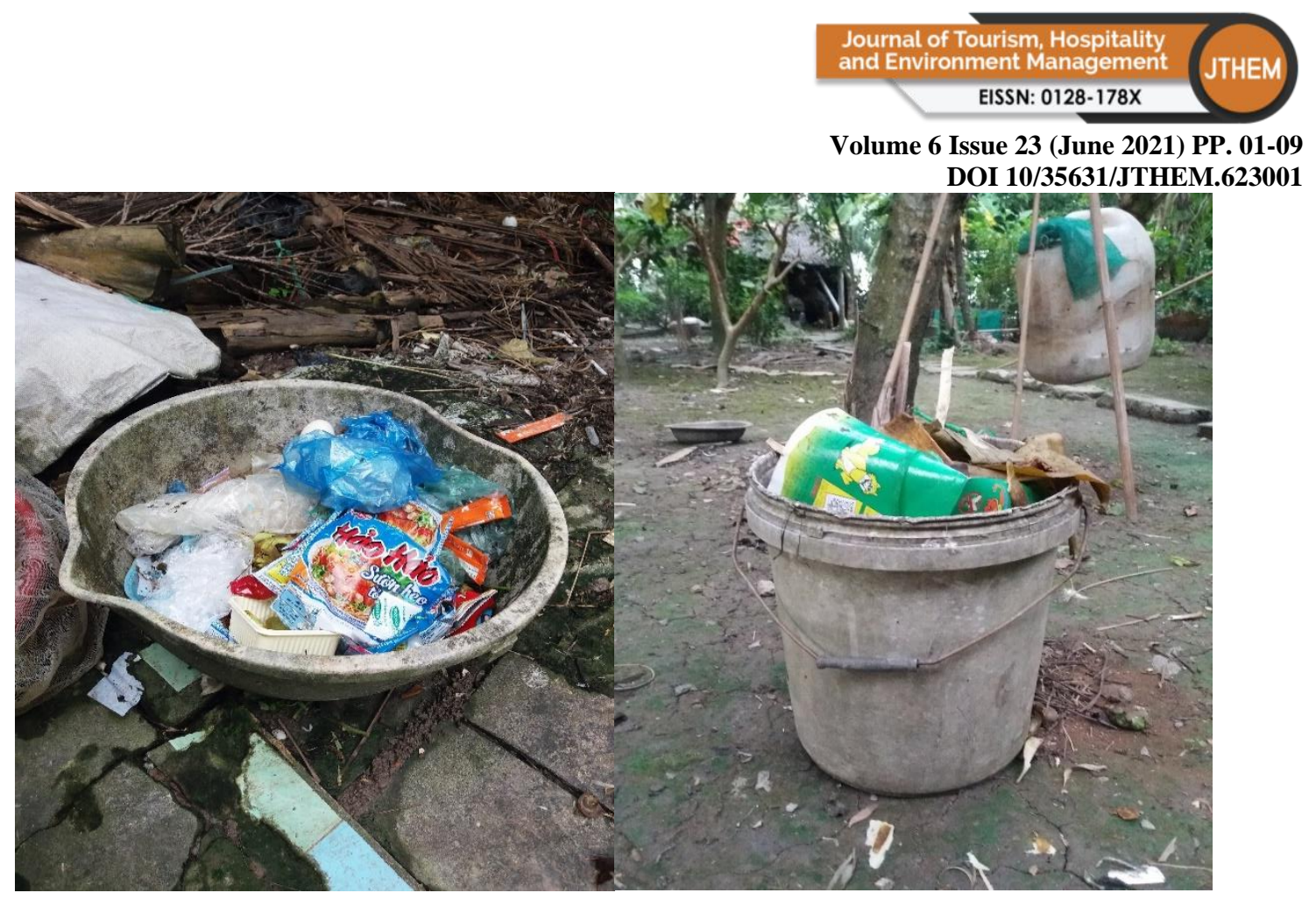

Figure 1. Waste Containers in The Household

The disposal method of large-sized electronic devices (e.g., televisions and refrigerators) is selling for scarp collectors while small devices (e.g., remote controls, table lamps) can be thrown away into the surrounding environment. Interestingly, $100 \%$ of respondents agreed that they would remind people who litter the environment indiscriminately. This result is in contrast to previous discussions that the respondents' awareness about environmental protection is not high.

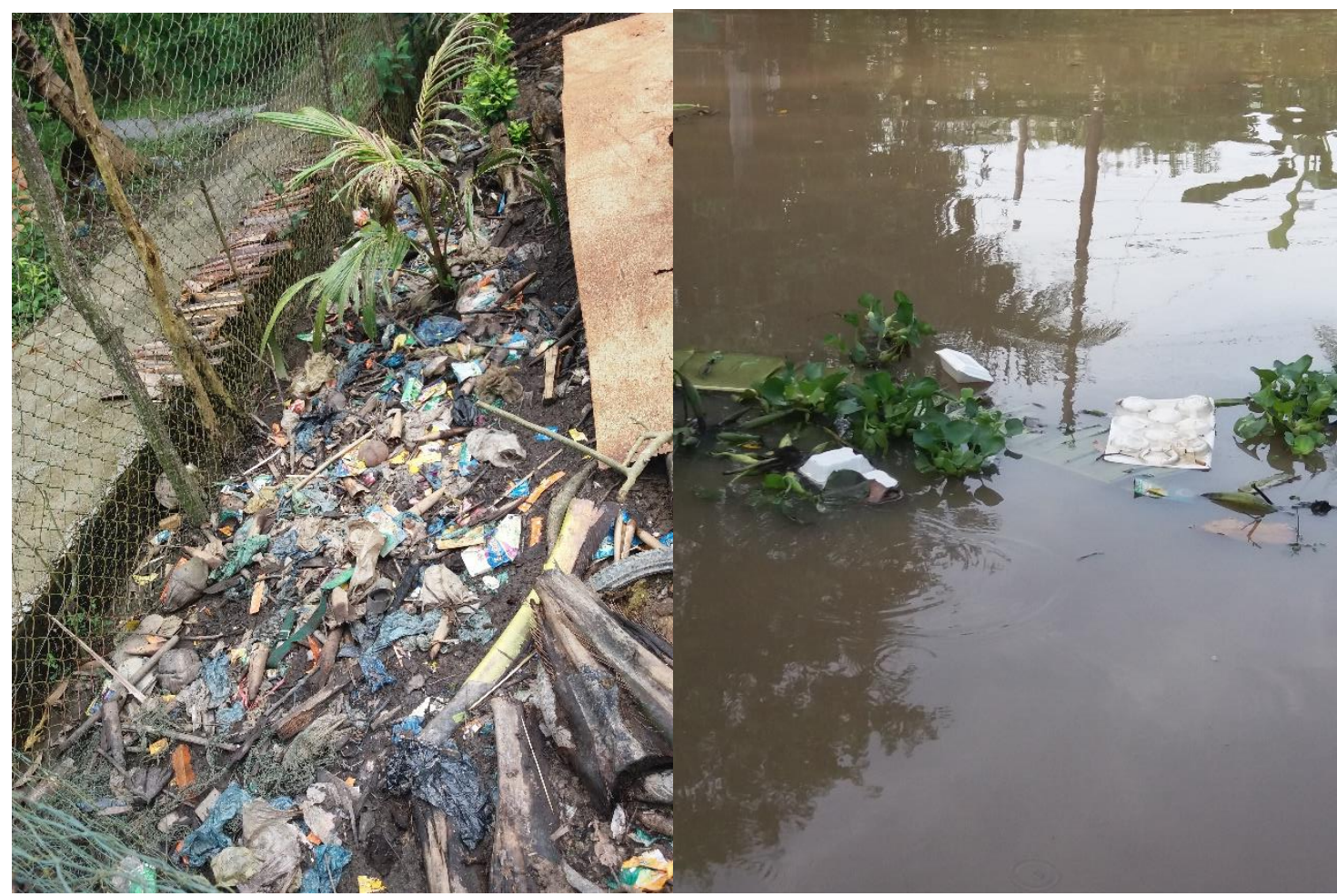

Figure 2. Improper Solid Waste Disposal in Vinh Trung Commune, Hau Giang Province 


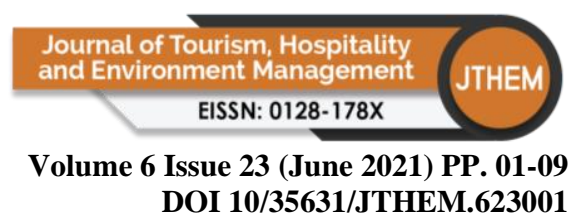

\section{Conclusions}

The results show that the amount of produced solid waste is $0.9 \mathrm{~kg}$ per household per day with an average of $0.24 \mathrm{~kg}$ per capita per day. The composition of collected solid waste contains $85.43 \%$ of organic waste, $13.94 \%$ of reusable waste and $0.64 \%$ of the remaining waste excluding hazardous waste. Currently, there is no solid waste collection and treatment system in the study area. Most of the people have good knowledge (93.33\%) and good attitudes towards solid waste-related issues. However, their practices completely go against the results of previous knowledge and attitudes. To overcome the current problems, the investment for a solid waste collection and treatment system is absolutely necessary. In addition, proactively improving knowledge for local people of local authorities should be implemented simultaneously to build a more sustainable living environment.

\section{References}

Ajah, K. C., Ademiluyi, J., Nnaji, C. C. (2015). Spatiality, seasonality and ecological risks of heavy metals in the vicinity of a degenerate municipal central dumpsite in Enugu, Nigeria. Journal of Environmental Health Science and Engineering, 13, 1-14.

Dieu, T. T.M., Truong, L. M. and Viet, N. T. (2013). Composition, volume of domestic solid waste from households and the ability to recover and recycle: Case study in District 1, Ho Chi Minh City Chi Minh.

Giao, N. T.; Ai, T. T. M., Nhien, H. T. H. (2020). Evaluation of current water use situation and water quality in Tan Thanh commune, Thoi Lai district, Can Tho city. Journal of Natural Resources and Environment, 30, 10-20.

Giao, N. T. (2020). Potential health risk assessment for the occurrence of heavy metals in rice field influenced by landfill activity in Can Tho City, Vietnam. International Journal of Environment, Agriculture and Biotechnology, 5(4), 928-935.

Hang, N.T. (2015). Domestic solid waste management Vung Tau city, Ba Ria-Vung Tau province until 2030 with the participation of the community. Master Thesis majoring in Urban Management, Hanoi Architectural University.

Hanh, Đ. T. M. (2016). Increasing community participation in domestic solid waste management in Kim Dong district, Hung Yen province. Master thesis Ho Chi Minh City University of Economics.

Kingsawat, R., Roachanakanan, R. (2011). Accumulation and distribution of some heavy metals in water, soil and rice fields along the Pradu and Phi Lok canals, Samut Songkhram province, Thailand. Environment and Natural Resources, 9(1), 38-48.

Klinsawathom, T., Songsakunrungrueng, B. \& Pattanamahakul, P. (2017). Heavy Metal Concentration and Risk Assessment of Soil and Rice in and around an Open Dumpsite in Thailand. EnvironmentAsia, 10(2), 53-64.

Linh, L.G. (2019). Knowledge, practice and current situation of solid medical waste management and some related factors at Vinh Phuc Provincial Psychiatric Hospital in 2018. Doctoral thesis, Hanoi Medical University.

Ministry of Natural Resource and Environment (2017). National environmental status report about solid waste management in 2017. Ministry of Natural Resource and Environment, Hanoi, Vietnam.

Nam, P. V. (2016). Determining the household's willingness to pay for domestic waste collection service in Quy Nhon city, Binh Dinh province. Master thesis Ho Chi Minh City University of Economics. 
Volume 6 Issue 23 (June 2021) PP. 01-09 DOI 10/35631/JTHEM.623001

Nhien, H. T. H. \& Giao, N. T. (2019). Environmental soil, water, and sediment quality of Dong Thang landfill in Can Tho City, Vietnam. Applied Environmental Research, 41(2), 7383.

Nhue, T. H. \& Cong N. Q. (2005). Research and study on organic waste management of Bai Chay tourist area, Ha Long city. Culture and Information Publishing House, Hanoi.

Phu, N. (2016). Management of domestic solid waste in Hoi An city until 2030 with the participation of the community. Master Thesis majoring in Urban Management, Hanoi Architectural University.

Viet, L. H. and Chiem, N. H. (2013). Curriculum on solid waste management and treatment. Can Tho University Publishing House. 